\title{
EU Clinical trial regulation in the environment of rare diseases: time for a change
}

\author{
Martine Zimmermann \\ From 5th European Conference on Rare Diseases (ECRD 2010) \\ Krakow, Poland. 13-15 May 2010
}

The clinical trial directive $2001 / 20$ /EC is out for public consultation. This session will draw the attention of the challenges faced by Small and Medium Enterprises (SME) companies when developing new products for the rare diseases that affect a very limited number of patients and discuss possible options to overcome the challenges.

Indeed, with only a few patients in each country, clinical trials need to be conducted in many countries in order to enrol the number of patients required to demonstrate benefit/risk. The management of these clinical trials is associated with several issues that slow down the overall process of drug development: administrative hurdles associated with non harmonised regulatory authorisation process as well as cost pressure linked to the need to outsource local activities to several consultants to prepare and manage submission to health authorities and ethic committees.

Today, Europe must streamline its system and all stakeholders should raise their voice to propose specific approaches in order to facilitate the development of new drugs for orphan drugs in a timely manner.

Published: 19 October 2010

doi:10.1186/1750-1172-5-S1-P19

Cite this article as: Zimmermann: EU Clinical trial regulation in the

environment of rare diseases: time for a change. Orphanet Journal of

Rare Diseases 2010 5(Suppl 1):P19.

Correspondence: zimmermannm@alxn.com

Director Pharmaceutical affairs, ALEXION EUROPE, 25 boulevard de I'Amiral Bruix, 75016 Paris, France

Submit your next manuscript to BioMed Central and take full advantage of:

- Convenient online submission

- Thorough peer review

- No space constraints or color figure charges

- Immediate publication on acceptance

- Inclusion in PubMed, CAS, Scopus and Google Scholar

- Research which is freely available for redistribution

Submit your manuscript at www.biomedcentral.com/submit
BioMed Central 